(192)

\title{
イエバエ幼虫の発育に及ぼす密度効果
}

\section{Effects of population density and its phase change on the development of the housefly larvae}

\author{
北岡茂 男* \\ Shigeo Kitaoka
}

イエバエは人畜衞生上に広範な関連学持つているた め, 化学的駆除の一形態として殺虫凧の適用方法が種心 研究されている己共に, 殺虫削の效力検定の及定目的已 しても甚だしばしば用いられている供試昆虫の一つであ る. 殺虫浭の生物試験のための昆虫が備えるべき諸条件 こして,一年定通じて実験室内の飼育が容易ですり，世代 放短かく一㭙に大量の供試数が得られ，累代飼育により 抵抗性々その変異の愊が変らず,生活力,繁殖能力が減退 しない事等が重要な事であり，イェバェは以上の条件の

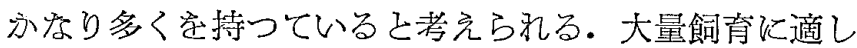
た幼虫の培養としては，Richardson (1932)，Basden (1947) , Frings (1948), Hafez (1948), Moreland \& McLeod (1947) 等が報告し, Peet-Grady 法の C.S。 M.A. 培基，我国では長沢 (1952) の豆腐粕培養等がか なり一般に用いられている椂である.イェバェの発育, ひいては外的要因に対する抵抗性に大きな影響学与える ものは, 培基の種類, その水分量, 飼育密度等で, 長 沢 (1952) ほ 馬冀培基巨豆腐粕培基で飼育した成虫の $\mathrm{pp}^{\prime}$-DDT に対する 抵抗性に一定の傾向の差がある事走 報告し, また, 石倉・尾崎 (1953) はアズキゾウムシの BHC に詨する抵抗性が飼育密度にょり変化ずる事定認 めている.

本報告は小動物用固型飼料 こフスマよりなる培基でイ エバエ幼虫を種从の密度で飼育した際の蛹の体重, 蛹化 率, 蛹化継続日数に及汸す影響を調べ, 密度効果に見ら れる相の変化さ, 飼育最適密度について考察を行なつた ものである。

\section{実験材料及び方法}

実験に用いたイエバェ (Musca domestica vicina MACQ.) 证伝染病研究所構内で採集され, 昭和 30 年以来累代 飼育された系統のものである. 幼虫飼育培基己してはオ リェンタル醭母株式会社製小動物用固型飼料( ツト，ハムスター用M) を粉末こしたもの25 g とフスマ

\section{* 農林省家畜衙生試験場}

National Institute of Animal Health
$25 \mathrm{~g}$ 学水 $50 \mathrm{cc}$ で充分混和し, 直径 $9 \mathrm{~cm}$, 高さ $6 \mathrm{~cm}$ の腰高

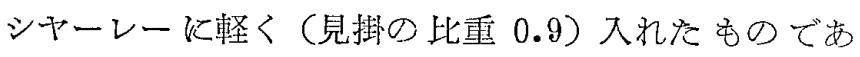
る. 同培基字羽化後約 1 週間の成虫のかでの中に入れ， 一晚産卵させた後に取り出し， $25^{\circ} \mathrm{C}$ 恒温器中に置き翌日 新しい培基の中に幼虫学 $20 ， 80 ， 160 ， 320 ， 640 ， 1280$, 2560 匹の 2 の幾何級数的 7 段階已補足のための中間值， 960，1920匹の 2 段階より成る個体群として移し入れ た. 幼虫を移し入れた培基恃さらし布で被い，ゴムバン ド空かけ $25^{\circ} \mathrm{C}$ 恒温器中で飼育定行なつた。蛹化前日に培 基上に脱脂綿学拡げそこで蛹化させ，尘卵開始から 9 日 目に蛹を取り出し20～80匹では全個体につき，160匹以 上の区に於ては 100個体につき，それぞれ個体別にトー ションバランスで体重を測定した。 60匹以上の区では蛹: 化が完了していなかつたので16日目迄の㛚化個体数定数 えた。9日目迄の未蛹化個体数は僅汃，又9日目迄の 個体己の体重值に大きな差は誌められなかつた。各密度 区につき 1〜9回の繰返し学行なつた. 長沢 (1956) の

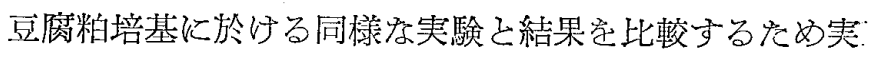
験 No. 3 5 では各密度区から30個体字無作為的に取り 出し, 双眼顕微鏡のミクロメーターで体長孛測定し, 実 験 No. 6 の個体群につき 7 31 mg の閒の各体重段階に. つき20個体 (1 mg 間隔で, 個体数少数の段階で恬20匹. 以下）を選び出し，体長宅測定した。

\section{実験結果及び考察}

各密度区に於て得られた蛹の体重の度数分布状態を表: として表1に，分布図こして図1飞示した. 各実験区に 於ける平均体重, 標準偏差, 変異係数, 実験区間の分散 を除いた変異係数, 奏験区間の不偏分散の值定表 2 亿示 し, 平均体重以標準偏差の巾を取つて図 2 上端に, 変異: 係数注 2 の中央にそれぞれ目示した。度数分布の形性 20，40匹の低密度区では小型個体注現われないため左傾 歪偏の型定取り，80匹以上の区では小型個体の出現によ り左側に裾を引き対称型に近づいている. 320匹迄の区 間ではモード及び分布位置に著しい移動がないが，640 匹以上では全体的に著しく左方に移つてしまう。長沢 
Table 1. Frequency distribution of weight of pupae of the common housefly reared under different population densities of larvae.

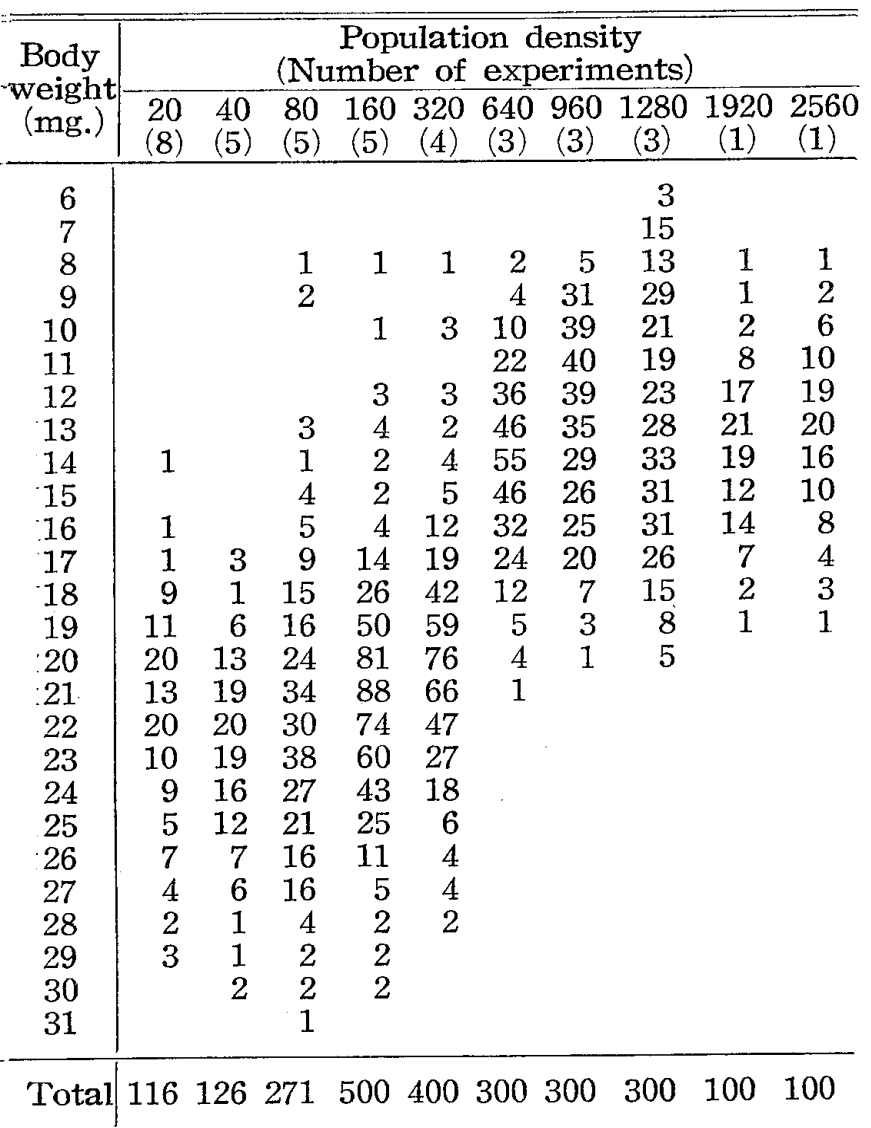

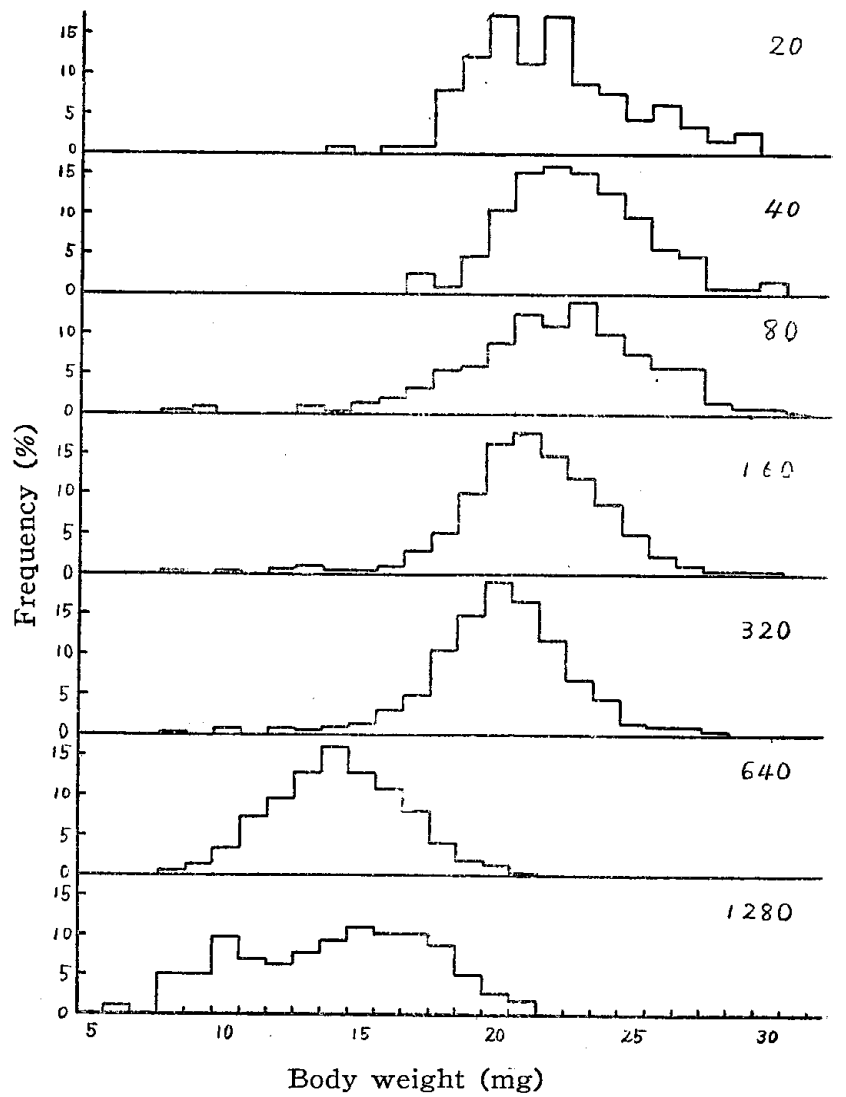

Fig. 1. Histogram for the distribution of body weight of pupae of the common housefly reared under different population densities of larvae.

Table 2. Mean body weights and their standard deviations of pupae of the common housefly reared under different population densities of larvae.

\begin{tabular}{|c|c|c|c|c|c|c|c|c|c|c|}
\hline \multirow{2}{*}{$\begin{array}{l}\text { Experiment } \\
\text { No. }\end{array}$} & \multicolumn{10}{|c|}{ Population density } \\
\hline & 20 & 40 & 80 & 160 & 320 & 640 & 960 & 1280 & 1920 & 2560 \\
\hline 1 & $\begin{array}{r}23.94 \\
3.09\end{array}$ & & & & & & & & & \\
\hline 2 & $\begin{array}{r}20.11 \\
3.37\end{array}$ & $\begin{array}{r}21.65 \\
3.15\end{array}$ & $\begin{array}{r}19.35 \\
3.70\end{array}$ & $\begin{array}{r}20.84 \\
2.65\end{array}$ & & & $\begin{array}{r}15.08 \\
2.42\end{array}$ & & & \\
\hline 3 & $\begin{array}{r}21.86 \\
1.68\end{array}$ & $\begin{array}{r}22.43 \\
2.14\end{array}$ & $\begin{array}{r}21.00 \\
4.12\end{array}$ & $\begin{array}{r}20.80 \\
2.78\end{array}$ & $\begin{array}{r}19.34 \\
2.61\end{array}$ & & & $\begin{array}{r}16.06 \\
1.96\end{array}$ & $\begin{array}{r}14.24 \\
2.10\end{array}$ & $\begin{array}{r}14.61 \\
2.29\end{array}$ \\
\hline 4 & $\begin{array}{rr}20.36 & 20.78 \\
1.22 & 2.97\end{array}$ & $\begin{array}{r}21.39 \\
1.87\end{array}$ & $\begin{array}{r}20.15 \\
2.05\end{array}$ & $\begin{array}{r}20.10 \\
1.69\end{array}$ & $\begin{array}{r}19.27 \\
2.59\end{array}$ & $\begin{array}{r}13.99 \\
2.03\end{array}$ & & $\begin{array}{r}10.99 \\
1.62\end{array}$ & & \\
\hline 5 & $\begin{array}{rr}24.16 & 21.25 \\
2.34 & 2.75\end{array}$ & $\begin{array}{r}24.81 \\
2.21\end{array}$ & $\begin{array}{r}24.87 \\
2.62\end{array}$ & $\begin{array}{r}23.29 \\
2.38\end{array}$ & $\begin{array}{r}21.44 \\
2.79\end{array}$ & $\begin{array}{r}13.92 \\
2.17\end{array}$ & $\begin{array}{r}11.10 \\
1.86\end{array}$ & $\begin{array}{r}11.74 \\
2.43\end{array}$ & & \\
\hline 6 & $\begin{array}{rr}21.21 & 22.38 \\
3.09 & 2.10\end{array}$ & $\begin{array}{r}22.66 \\
2.12\end{array}$ & $\begin{array}{r}23.32 \\
1.96\end{array}$ & $\begin{array}{r}21.09 \\
2.71\end{array}$ & $\begin{array}{r}20.29 \\
2.80\end{array}$ & $\begin{array}{r}14.41 \\
2.27\end{array}$ & $\begin{array}{r}11.93 \\
1.88\end{array}$ & & & \\
\hline $\begin{array}{l}\text { Mean } \\
\text { S. D. }\end{array}$ & $\begin{array}{r}21.85 \\
2.92\end{array}$ & $\begin{array}{r}22.73 \\
2.54\end{array}$ & $\begin{array}{r}21.98 \\
3.55\end{array}$ & $\begin{array}{r}21.22 \\
2.73\end{array}$ & $\begin{array}{r}20.09 \\
2.74\end{array}$ & $\begin{array}{r}14.10 \\
2.33\end{array}$ & $\begin{array}{r}12.70 \\
2.68\end{array}$ & $\begin{array}{r}12.89 \\
3.47\end{array}$ & $\begin{array}{r}14.24 \\
2.10\end{array}$ & $\begin{array}{r}14.61 \\
2.29\end{array}$ \\
\hline $\begin{array}{l}\text { Variation } \\
\text { Coeff. }(\%)\end{array}$ & 13.4 & 11.2 & 16.2 & 12.9 & 13.6 & 16.5 & 21.1 & 26.9 & 14.8 & 15.7 \\
\hline
\end{tabular}

（1956）の体長己体巾の分布型では低密度区では反対に 右傾的であるが，豆腐粕培基の栄養価值は本培基， C.S.M.A. 培基や Bran-Alfalfa 培基 (Moreland \& Mc
Leod，1957）に比し劣ると思われるので最適密度に於 ても栄養的に满足された条件にあつたか疑問である. 平

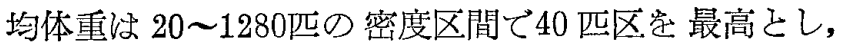




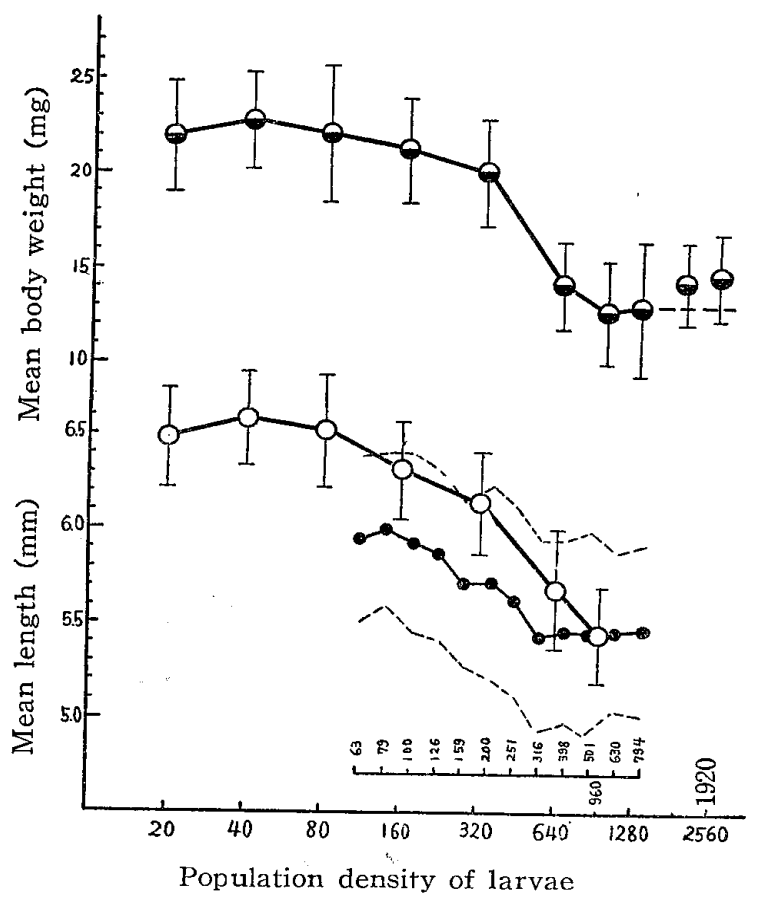

Fig. 2. The mean body weights and the mean lengths of pupae of the common housefly reared under different population densites of larvae. Mean body weight: mean length : - - - mean length in Nagasawa's data (1956) :

320匹迄次第に減少の傾向学取るが，640匹区になる己 急激に減少し，2560匹迄は変動の大きさ注深添一定の水

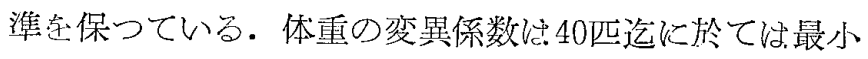
で, 高密度区では著しく高くなるが, 実験区間の分散安 除く々密度増加に伴ない漸増の傾向を示すのみであつ た。実験区閒の不偏分散につき $\mathrm{F}$-検定学行なつて見る と 320匹区を除いては実験の繰返しの間の体重值の変動 が有意か，非常に有意な差がある。 Moreland \& McLeod (1957） も標潐条件で C.S.M.A. 培基の繰返し飼育 の間にかなり大きな原因不明の変動が現われる事を認め ている. 図 2 下端には20～960元の密度区間に於ける平 均体長定之の標準偏差の巾を取つて, 長沢 (1956) の值 はこれ党m数に換算し，その用いた密度数定之え比較 して図示し\%。平均体長は体重に於ける己同様滵度増 加に伴ない次第に減少与るが，320匹区さ640匹間の著 しい変化法明瞭には示されない。長沢の結果上の比輘は 培基の種類，培基量が相違するためいかなる基淮学用い れば妥当であるが考慮の余地があるが，使用培基当り の個体数が等しくなる様にして比較した．960匹区を除 いて総ての密度範丑で本培基の蛹の体長が大きく，栖準 偏差の值も小さい事が認められる. 長沢の体長のグラフ は 316 794 匹区間でほざ水平さ成り，一定密度以上で
织蛹の体重は最低水準学保つという著者の想定を支持す⿹

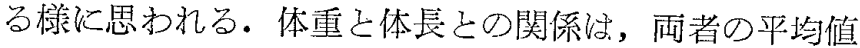
を両対数尺上にプロットすると拣ら゙直線さなり次の椂な 関係式が求められた（図 3 ).

$$
W=0.0975 L^{2.99}
$$

W 体長の 3 乘に比例与る箱であるからLの指数 $2.99 \fallingdotseq 3$ で 漂ざこの関係学満足している. 表 1 亿見られる如く本培 基で得られた最大体重は $31 \mathrm{mg}$ ，最小体重恬1280匹区の 1 シヤーレーに於ける $6 \mathrm{mg}$ 学除け将普通 $8 \mathrm{mg}$ であつ た。以上の関係式次ら推定した長沢の豆腐粕培基に於け る最大体重々同䅵に31 mg であるが，最適密度の73匹区 等除け林いずれの密度区に於いても本培基では出現しな かつた様な著しく小型の個体が見られる.Basden(1947) が認めた如く培基の水分量注均一大きさのもの学得るた めの重要な因子で，豆腐粕培基で活本条件定均一に保つ 事は困難であり，購入店による組成の差は当然考虑に 入れなければならない。との点本培基は組成，水分量の 均一化はょり容易で，栄養的な質に於いても優れている

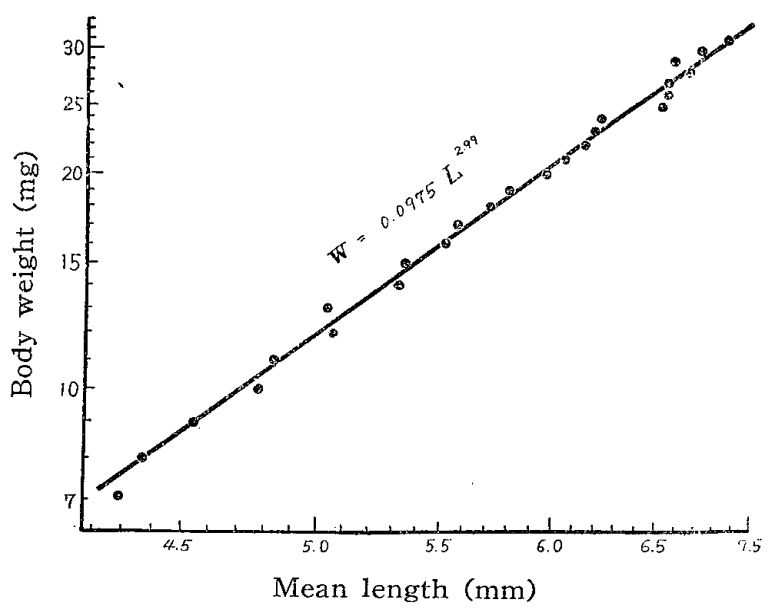

Fig. 3. The relation of the body weight and the mean length of pupae of the common housefly.

事は以上の結果办ら明ら汃である。体の大きさが最低密 度より少し高い所で最大となる同様な事実深森(1951)が Drosophila の早で，長沢(1952)惊アッ゙キゾウムシ ( Collosobruchus chinensis) 飞於いても認めている.

イエバエの飼育密度は体色にも著しい影響孛興え，体 重乞の相関に於て現す机る。即与大きな個体程黑色化し, 小さくなる程淡色化して，640匹以上の密度区の蛹蛙明 るい赤褐色已なる，昆虫の表皮の黒化及び硬化恬，表皮 中の蛋白成分が tyrosine 亦誘導され究 phenol 性物 質の tanning 作用により， sclerotin と cuticlin が形 成されるをめと考えられ，Sarcophaga の团蛹形成封に血. 中永ら tyrosine が趇皮比る集る事が知られている(Wig" 
Table 3. Number of pupae of the common housefly reared under different population densities of larvae.

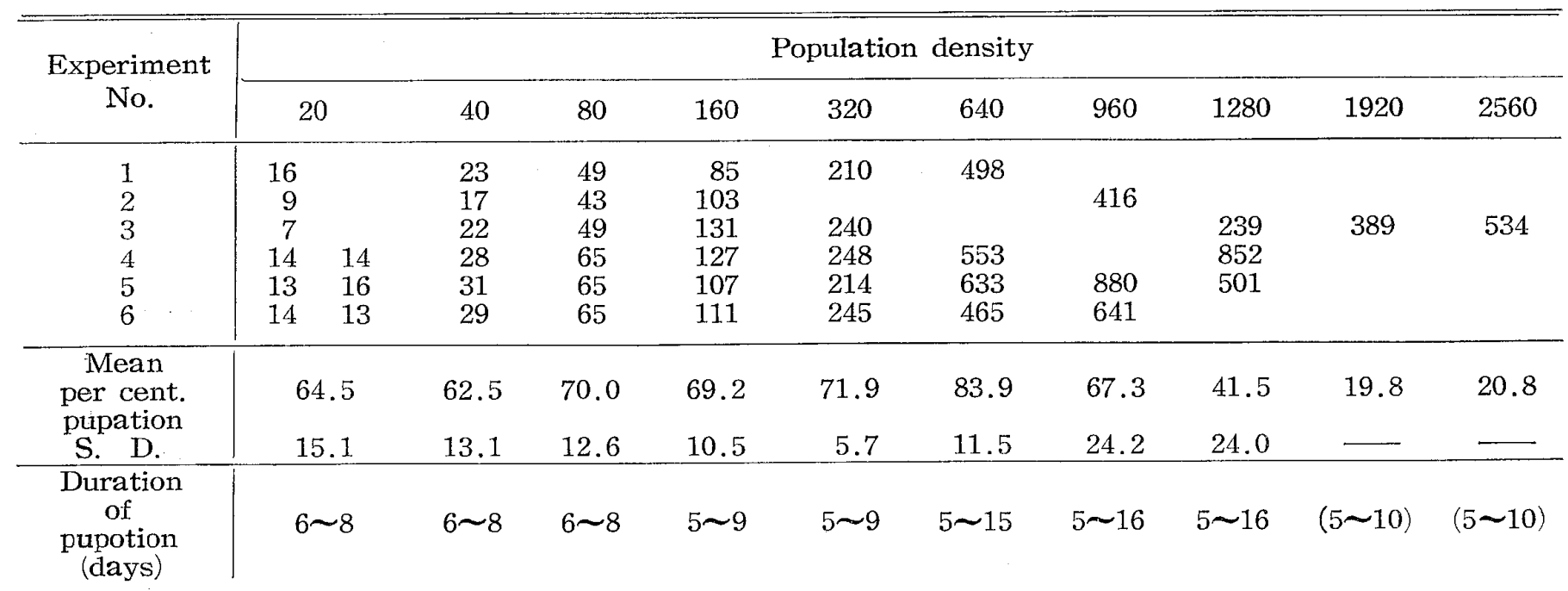

glesworth, 1950).孷 (1956) はアワヨトウ (Leucania unipuncta), 平田 (1956) はヨトウガ (Barathra brasicae) の高密度飼育によ子黑化現象定昆虫群集の相変化 と関連して現われるものと見ているが，イエバエで反対 に体色に現わ阮る淡色化惊，高密度に於ける幼虫の栄養 的要因の久乏定通じて tanning の過程燝影響受ける もの己考穵られる。

種心の個体密度区に於ける蛹化個体数，犕化率，乙の 変動係数，蛹化継続日数学表 3 に示した。蛘化率は20 640匹区閒では漸次上昇の傾向军示し，640匹区宏頂点 こして高密度になるこ急激に低下した。蛹化率の変動係 数惊 320四区に於て最も小さく，密度が低くなつても高 くなつても大きくなり, 特に高密度の時に著しかつた。 座畉開始日から数えて, 蛹化が行われている期間は40〜 80匹区では 6 8 日目，160〜320 匹では5〜9日目で 僅吕に延長されるが, 個体数増加に伴な弓分布巾の桩大 己解される程度であるが，640匹区上では著しく延長 され $5 \sim 16$ 日目己成つた。蛹化個体数が少ない場合む, 1920 己2560匹の各1例ずつの結果に見られる如く延長は 著しくなく，継続日数は主さして 3 令到達個体数の大小 に支配された。 Moreland \& McLeod(1956)方培基に接 種する畉量が多くなる上纤虫期日が延長される事字見， Sang (1949) は Drosophila k於ても或る密度以上に成 る己幼虫期間が長くなる事定観察している. 约虫個体密 度亡蛹化個体数及びその全重量定対数グラフルプロツト して見ると, 蛹化個体数は20〜640匹区で, 崅全重量活 20〜 320匹区で個体密度さの間に直線的関係が認められ (两直線己も $\chi^{2}$ の確率は $99 \%$ 以上)るが, それ以上の密度 区に於ては直線から全く離れてしま $3($ 図 4). 回㴆直線 傾斜注蛹佃体数に対し $b_{n}=1.078 \pm 0.140$ （95\%信 頉限界), 蛹全重量に対し $b_{w}=1.014 \pm 0.106$ (95\%信頼

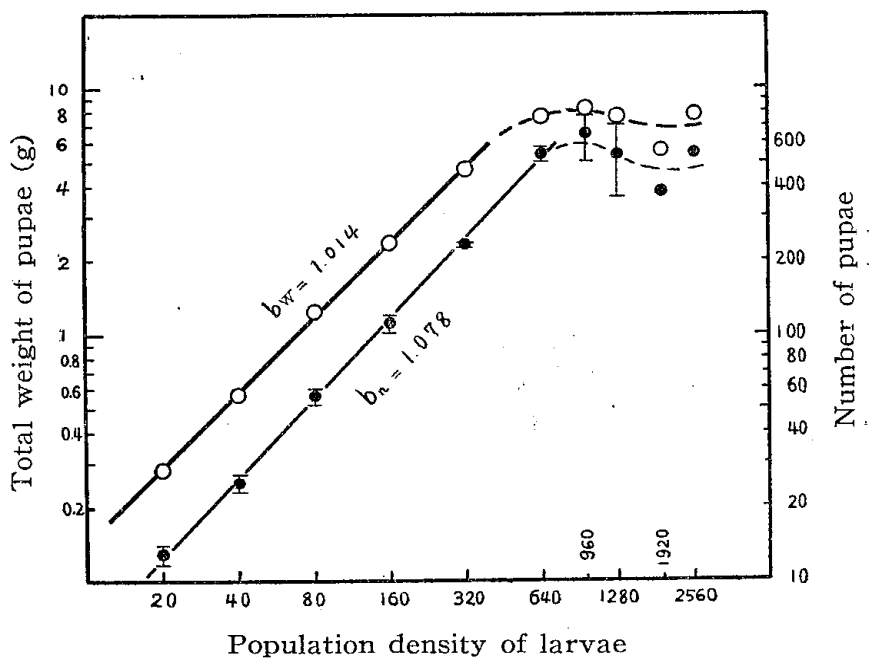

Fig. 4. The relations between the population densities of larvae and the mean mass weight (- - ) and the mean number of pupae (-- : showing the limits of standard errors).

限界）である. 両者乞もその傾斜性 1 より大いから僅

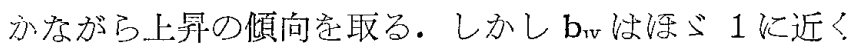
蛹全重量密度に正比例与当々考えてよい。平均体重に 対与る回帰直線の傾斜蚁 $b_{\mathrm{w}}-b_{\mathrm{n}}=-0.064$ で表す卞事が 出来, 体重惩度増加に伴ない減少の経過定示す事が判 るが，40四区で最大值学取る事実はこの表現法に於ては 変動䉓囲としてかくされてしまう. 或る密度以上に成名 己直線から背離する事は，密度效果に於ける相の変化が 起るためと考えられる. 以上の結果学生態学的な意味の 培基の持つ生産力の点から考察すると, 或る密度に達す 万迄は個体群の生体量 (biomass) 㹥密度比例 (densityproportional）であり，それ以上で情全重量は密度の

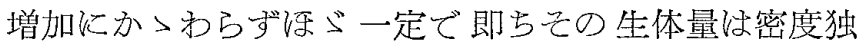
立 (density-independent) である. 特に生体量に於て 個体数に於的るよりの傾向が強いのは淘汰個体数の大 
(196)

衞 生 動 物

小により，体重が相補的认增減するためと考えられる。

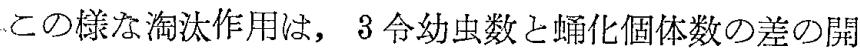
きが殆んぞない事実办ら見ても，食物の䋩対量が不足し ない様な 1 ～ 2 令の間似個体群の示す圧力によつて起と り, その結果個体群として発育可能な絶対量学碓保しう る有効な働きであると見なす事が出来る。表 2 の平均体 重上表 3 の蛹化個休数の值怯 640 匹以上の高密度区に 於いて著しく変县が見られるが，各実験区の個くの值に つき両者の相関を求めて見ると $\gamma=0.884$ の逆相関が認 められ，t-検定学行なつた場合 $1 \%$ 危除率伦於て有意な 相関がある己結論された。即ち密度独立の傾向学示すた めの体重已蛹の個体数の間の相補性が示された．以上の 場合，食物量が環境の制限因子と成つているが，Read

（1951），守屋（1951）恃ラットに寄生する矮小条虫

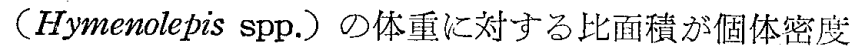
により,環境酸素分圧の不足の結果，相的変化它方事学 報告している. Sang（1949）は Drosophila の発育に及

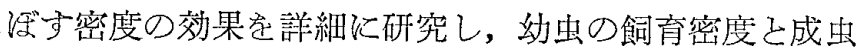

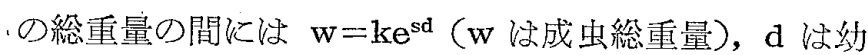
虫密度, $\mathrm{k}, \mathrm{s}$ 蛅恒数) なる関你式が通用されると述心゙ ているが，彼の報告の表 6 の数值につきその適合性を 、調へてて見ると，醉母接種量の多い場合学除いては上式が

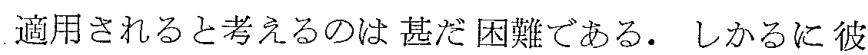

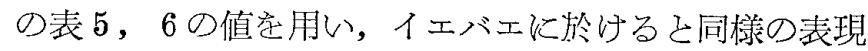
法を試及ると，Pearl の $\mathrm{S}_{101}$ 培基 (Pearl \& Penniman, 1926), $4 \mathrm{cc}$ 当り醉母 $14 \mathrm{mg}$ 学接種し\%場合禖 20 兀 迄，70mg の場合は50匹迄の間に直線関係が西り中間の

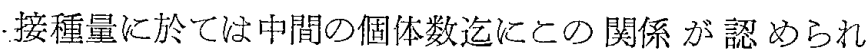
る. 接種量が少い程, 二相の存在は明磪であり, 接種量

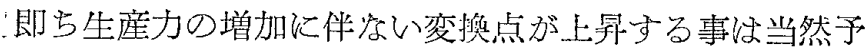
、想される。密度の大小により違つた相が現われる点办ら む, Sang (1949) がこれ党一つの式で表現しょうとし

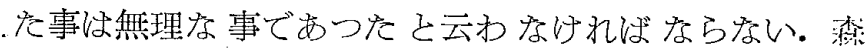
（1951）のコウジ培基（千野, 吉川, 1934））12cc当り 100匹の所㑑の変換点が認められ，その直線の傾斜恃 1 亿近いが, Sang(1949)のPearl の培基の場合活 1 上 り近く或る程度密度低存（density-dependent）の傾向 が認められる. Adolph (1931) は Rana pipiens の才夕 マジヤクシの発育が典型的店密度依存の例である事を示 しているが, 多くの生物の発育に及注す密度の效果性 3 つの型方移行的化或㹥組合わさつて現われるものと考元 る事が妥当であろう。

個体の発育に対する最適密度が，最低密度よりむしろ 少し高い所倸る事実を, Allee (1931) は Eigenbrodt が Drosophila で得を結果以対する分析で，余り低密度 であると培基内の微生物淿よる阻害作用定抑制する事が
1957 年 Vol. 8 No. 4

出来ないためと考え，Sang (1949) 祇醉母群集の発育已

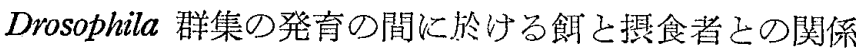
としての相互作用の鈎合い定原因々考えた。イエバェと 培基中の他の生物群集この相互作用はょり複教で, 培 基の質的変化をもたらす他に，その物理的条件にも著 しい影響を 興える. 幼虫密度が高い場合は培基中の力 ビの繁殖は全く阻止されて居るが，低密度の場合その繁 殖と培基の固化が見られ，幼虫の貫入学不可能已し利用 空間の物質量の制限, 乃至は好適環境の選択定不可能飞 するであるう。高密度となる程，培基全体が艮く混和さ れ，均一な状態となり蛹化時には乾燥した堆肥様にな る. 幼虫の排泄导るアンモニヤ・尿酸，その他の老廃物

（Brown，1936）や初令幼虫㭙の集塊化汇子る相互の接 触的な刺激もその要因の一つとして考えなければならな いが，無菌培基中の Drosophila の発亩に忹，最適密度の 存在が認められない事奏 (Sang, 1949) 亦らも培基中 の生物的要因との相互作用にその観点が置かれるべきで

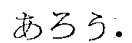

発育に対する最適密度定定める際に，その基準学個体 に置くか，群集に置くかにふり違つて来る．体の大きさ が最大となる密度心すしろ個体の見地に立つもので，得 られる個体数の点からも大量飼育の目的に柱不満足であ り, 最大值が最小密度に於いて見出される場合には，基 準としての発育最適密度定求める事山不可能である. 密 度効果の相の変化六らこれ考えれば, 密度已蛹総重量 即与生体量との間に正比例関係がある範囲では, 個体の 食物に対する要求絶対量证常に満足され, 相の変換点に 於て個体群当りの生体量㹥最大乞なる. 即与本培地の最

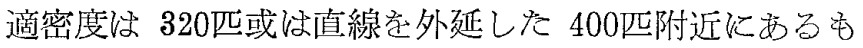
のと考えられる. ての密度に於ける体重の絶対值 (20.09 $\pm 2.74 \mathrm{mg}$ ) の大きさね，C.S.M.A. 培基と湮心゙同様な 成績学興えている Moreland \& McLeod(1957)の BranAlfalfa 培基《於ける連続的大量飼育の值 $20.8 \pm 0.9$ $\mathrm{mg}$ と比較して, 又標準偏差も彼等と同様に実験区の平 均について計算すれば士1.02で殆んぞ優劣は認められな い. 320匹区に於ては蛹化継続日数の著しい延長は起ら ず，蛹化率の変動係数が最小で実験の再現性が高い：今 培基環境己幼虫個体群上りなる一つの系考考光た場合, 低密度時には幼虫に対する環境の要因が，高密度時に は幼虫の環境に対与る作用がより強く働き, 初期条件の 僅加差はこの系の終点に於いて大きな振门さなり易い が，との二つの交互作用がフィード・バック機構字形成 するため，平衡関係にあると思わ䏓る相の変換点に於い ては大きな振巾が起り難いためと考えられる.

\section{結 論}

イエバエ幼虫定小動物用固型試料 $25 \mathrm{~g}$ ，フスマ $25 \mathrm{~g}$ ， 
水50ccより成る掊基で20２560匹の種々の個体密度で飼 亩し，蛹の体重，样長，蛹化個体数，蛹化継続日数に及 经す影響学調べた。

1）体重の度数分布型は低密度区に於いては右傾歪偏 ○傾向圭示すが，密度增加に伴ない効称型に近づく. 20 〜 320匹区ではキードや分布範囲に大きな変動はないが 640匹区以上では著しく左方に移動する.

2）平均体重㤝40匹区ほ於いて最大で，320日区迄は 密度の増加に従い漸次下降し，640匹区以上では急激に 減少し最低水準に達する。

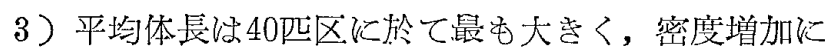
徒い次第に娍少した。長沢（1956）の豆腐粕培基の結果 こ比較してその值は，高密度区䒚除いて総ての密度範囲 で大きく，徱準偏差がより小さかつた。

4) 蛹化は 320匹区迄性座畉啳5〜8日の閒で完成す るが，640匹以上の密度区では著しく延長されしばしば 16日目にも蛹化不能の個体导生ずる.

5）蛹化個体数は 20〜 640 匹区で，蛹全重量は 20〜

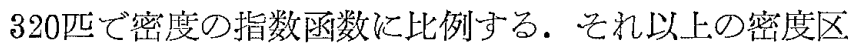
ではその直線性から全く離背し，との範围では蛹化個体 数こその平均体重の間に结逆相関があり，蛹の総重量が 一定值圭保つ方向に個体群の平均体重が増減文る。

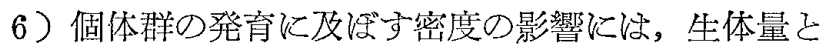
して密度に正比例する相と，密度独立の相が認められ b.

7）との二つの相の変授点は 320匹附近に方り, 培基 及び密度当り最大の生産量が得られ，且つ再現性が高く 本条件に於ける大量飼省のための最適密度に相応方るも のであると考えられる。

本笑験任東京大学伝染病研究所寄生虫部火内地留学中 1957年 1 月万至 3 月の間に行なつたもので主任佐々助教 授の御指導立びに研究室各位の御支援に対し深甚の謝意 表すると共に, 留学に際し種々御便宜を賜わつた小林 場長並びに矢島博士に敬意を表す。

\section{参考文献}

1) Adolph, E. F. (1931) : Biol. Bull. 61 : 350-375. -2) Allee, W. C. (1931) : Animal aggregation, Univ. of Chicago Press. -3) Basden, E.B. (1947): Bu1l. Ent. Res. 37 : 381-387. -4) Brown, A. W. A. (1936): J. Exp. Biol. 13 : 131-139. -5) Frings, H. (1948): Science $107: 629-630$, -6) Hafez, M. (1948) : Bull. Ent. Res. 39 : 385-386. -7) 平 函昼雄 (1956)：個体生態学の研究 III : 79-92. -8) 石倉秀次-尾崎幸三郎 (1953)：防虫科学 18:85-89. -9）綮俊一 (1956)：個体生態学の研究 III : 60-78. -10) Moreland, C. R. \& W. S. McLeod (1957) : J. Econ. Ent., 50 : 146-149. -11) 森主一(1951) : 動雑 $60 ： 106-109$ ，－12）守屋佮二(1954)：寄生虫
学雑誌 $3: 131-135$. - -13) 長沢純夫 (1951) : 個体生 熊学の研究 I：136-142. 一-14) 長沢純夫 (1952)：植 物防疫 $6: 393-395$. - 15) 長沢純夫 $(1952)$ ：防虫科 学 $17: 99-103$. -16) 長沢純夫 (1956)：防虫科学, 21 : 110-116. -17) Read, C. P. (1951): J. Parasit. 37 : 174-178. -18) Richardson, H. H. (1932): Science $76: 350-351$. -19) Sang, J. H. (1949) : Physiol. Zool. 22 : 183-202. -20) Wigglesworth, V. B. (1950) : The principle of insect physiology. London, Methuen.

\section{Résumé}

The effects of larval population density on the body weight, the length of pupae and on the duration of pupation using larvae of the common housefly, Musca domestica vicina MACQ. are presented in this paper.

As the culture medium of larvae, mixture of $25 \mathrm{~g}$ of powdered Oriental Compressed Diet for Experimental Animals (for a mouse, rat and hamster), $25 \mathrm{~g}$ of wheat bran and $50 \mathrm{cc}$ of water kept in a petri dish measuring $9 \mathrm{~cm}$ in diametar and $6 \mathrm{~cm}$ in height were prepared. The population of larvae were chosen in twofold steps as $20,40,80160,320,640,1280$ and 2560 individuals respectively and some middle scales as 960 and 1920 were added supplementally. Second day's batches of larvae were transferred to dishes and all pupae were served for measurement after 7 days which were cultured at $25^{\circ} \mathrm{C}$.

Frequency curves of body weight were biassed towards lighter side of the mode in lower population densities. As population densities increase, their forms approached to the normal distribution. The curves moved towards the lighter side in a remarkable degree when densities were 640 or more individuals (Fig. 1). The maximum value of body weight was obtained at the density of 40 individuals, and the body weight decreased gradually as the increase of population density up to 320 , but it decreased remarkable when the density rose to 640 . It seemed that the lowest level was kept within certain limits of fluctuation in higher population densities. Mean lengths of pupae were longer and their standard deviations were smaller in a range of wider population densities compared with Nagasawa's result using " okara" (residual product of bean-curd) medium (Fig.2). The pupation was accomplished from 5 to 9 days after the oviposition in the population densities between 20 and 320 individuals, but the duration prolonged from 5 to 16 days when the population density attained over 640.

The mass weight as well as the number of pupae recovered at various population densities 
樆 生 動 物

were plotted on the double logarithmic scales. The value fitted well in linear regression in the range of from 20 to 320 larvae in the former and from 20 to 640 in the latter, but were dislocated from them in higher population densities, suggesting there existed another phase of population effects (Fig. 4). Furthermore, a significant negative correlation was seen between the number of pupae recovered and their body weight in the dislocated part. From the ecological concept, the productivity of culture medium will be expressed as density-proportional to the biomass until the population density reaching 320 individuals, as density-independent when over that densiy it sustains constant biomasses for a results of intraspecific competition which would been occurred by the population pressure.

The population density of 320 individuals was assumed the optimum for mass culture of the common housefly under this culture condition from the following facts. Under this population density, no distinct decrease in the body weight was demonstrated comparing with those of lower populations. The rate of pupation in the density of 20 to 640 increase in some degree, but 320 group showed the best reproducible results. Until 320 individuals, duration of pupation little varies in the increase of the population density.

\title{
ヒメイエバエ Fannia canicularis L. の発生源に関する知見
}

\author{
Some notes on the hahitats of early stages of Fannia \\ canicularis L. in the northern part of Japan
}

緒方 一喜1）鈴 木 猛2) 長田 泰博2) 本社俊之助2)

Kazuki Ogata, Takesi Suzuki, Yasuhiro Osada and Shunnosuke Hirakoso

ヒメイエバエ Fannia canicularis はイエバェ Musca vicina 己共に, 衞生害虫こして我が国に於ては最も重要 な屋内侵入性の種類である。特に北日本に於てはイエバ エを倰いで,一般家屋内の優占位点占める。（堀1950, 中 道ら1955)

近年我が国に於ける八エの駆除柱特に幼期の発生源対 策が重点的に取り上げるれているが，その基礎こもなる べき発生源己発生種関する研究性数少く，この面の解 明は現地から要請される所が大きい。

筆者ら以，北海道芦別町三菱鉱業芦別鉱業所住宅地区 《於兴衞生害虫駆除の実施に当つて, 当地区内の八エ の発生源調查及び活動成虫調查など二・三の基礎調查を 行う機会在得たが，その結果，ヒメイエバエの発生源に ついて非常に興味ある資料学得たのて，更に，道内，東 北, 関東地方で, 漁村, 農村, 住宅地字迩び同样な調查

1）国立予防衞生研究所衞生昆虫部 Dep. of Med. Ent., National Institute of Health, Tokyo

2) 東京大学伝染病研究所寄生虫研究部

Dep. of Parasit., Institute for Infectious Diseases, University of Tokyo
长行つた.

本報告では上上の結果について述べ, 更に従来の知芫 学も併せて，ヒメイエバエの発生源についての考察学試 みたものである。

本調查を行らに当つては, 各方面の方々の御指導, 御 協力, 御援助を得た。予研衞生昆虫部長朝比奈正二郎博 士, 伝研寄生虫研究部佐々学博士には, 常日頃御愁篤な 御指導を仰いでいる. 東京医科歯科大学加納六䬦博士か らは種々有㚇な御教示を頂き，文献の御貸与を頂いた。 三菱鉱業株式会社労働部野村正男氏，小川皆男氏には， 本調查の穖会を与えられ，種々御援助を頂いれ。三菱鉣 業健康保険組合本部獅々堀猛氏, 芦別支部茶木, 船木雨 氏, 北海道庁衛生部松井貞夫氏, 小樽保健所所長熊谷直 之氏他所員の方々, 東京都衞生局安元宗一郎氏, 神奈川 県衞生部内田三郎氏及び大曲方寺邑誠祐博士には直接 飞調查の御援助を頂いた，值江津保健所堀田貞作氏より は貴重なる資料を御教示頂いた。 以上の方々に，心から 厚く御礼申し上げる。

\section{調査方法及び結果}

\section{1. 調査場所及び日時}

北海道芦別町三菱鉱業芦別鉱業所社宅地区（炭鉱住宅 